\title{
IMMUNOGLOBULINS AND LIPID PROFILE OF CHILDREN WITH SICKLE CELL ANEMIA IN EKITI STATE, NIGERIA
}

\author{
OYEYEMI A O, OYEBANJI 0 G* \\ Department of Biochemistry, Ekiti State University, Ekiti State, Nigeria. Email: talktofisayo@yahoo.com
}

Received: 27 February 2018, Revised and Accepted: 31 May 2018

ABSTRACT

objective: Sickle cell disease (SCD) is a hereditary blood disorder characterized by an abnormality in the oxygen-carrying hemoglobin and associated with some acute and chronic health problems such as severe infections, severe pain (sickle cell crisis), and stroke. The aim of this study was to evaluate the levels of immunoglobulins (Ig) and the lipid profile in children with SCD in Ekiti state, Nigeria.

Methods: Samples of 200 children (120 sickle celled and 80 healthy children) between the ages of 1-8 years old were collected from Ekiti State University Teaching Hospital, Ado Ekiti and Federal Medical Centre, Ido Ekiti, Ekiti State, Nigeria. Plasma Ig (IgM and IgG) and lipid profile (total cholesterol [TC], high-density lipoprotein [HDL], low-density lipoprotein (LDL), very LDL (VLDL), and triacylglycerol [TG]) were evaluated in patients' blood sample using standard established methods. The results obtained were subjected to statistical analysis $(\mathrm{P}<0.05)$.

Results: Sickle-celled children showed a significant reduction in the levels of Ig (IgM and IgG). Furthermore, TC, LDL-C, VLDL-C, and TG showed significant higher value whereas high-density lipoprotein cholesterol was significantly reduced in sickle-celled patients compared with nonsicklecelled patients.

Conclusion: It is understood that sickle cell is detrimental to immunoglobins and metabolic profile. These biochemical makers determined were implicated in children with sickle cell anemia.

Keywords: Immunoglobins, Lipid profile, Sickle cell anemia.

(c) 2018 The Authors. Published by Innovare Academic Sciences Pvt Ltd. This is an open access article under the CC BY license (http://creativecommons. org/licenses/by/4. 0/) DOI: http://dx.doi.org/10.22159/ajpcr.2018.v11i9.25503

\section{INTRODUCTION}

Sickle cell disease (SCD) is a potentially devastating condition that is caused by autosomal recessive inherited binopathy, which results in the hallmark clinical sequelae of vascoclusive phenomena and hemolysis. The genetic abnormality is due to a substitution of amino acid valine for glutamic acid at the sixth position on the $\beta$-globin chain [1].

The red blood cells of people with sickle cell disorder, however, contain unusual hemoglobin - termed sickle hemoglobin or hemoglobin $\mathrm{S}$ (HbS). Hemoglobin S (HBS), hemoglobin produced as a result of this defect is a hemoglobin tetramer (alpha 2 /beta 52 ) that is poorly soluble and polymerizes when deoxygenated [1]. This undergoes changes after oxygen delivery, causing the red blood cells to alter shape - particularly when the level of the oxygen in the blood is reduced such as after exertion, and the cells become sickle shaped. Sickle cells are rigid and do not flow easily through the tissues. Normal red blood cells are shaped like discs or doughnuts with the centers partially "scooped out" and are soft and flexible; they can easily "squeeze" through even very small blood vessels [2]

The incidence of SCD exceeds that of most other serious genetic disorders including cystic fibrosis and hemophilia [3]. There are many types of SCD; the most common type includes sickle cell anemia (HBSS), the sickle beta-thalassemia $\left(\mathrm{HbSB}^{0}\right.$ and $\left.\mathrm{HbSB}^{+}\right)$, hemoglobin $\mathrm{SC}$ disease (HBSC), and SCD with hereditary persistence of fetal hemoglobin (S/HPFH) (HBSS) [3].

SCD children have impaired immune response and are uniquely vulnerable to infections, such as malaria, which is a common trigger of vaso-occlusive crisis in patients living in malaria-endemic countries. Some clinical features include anemia, severe pain, chest pain, pallor, strokes joint pain, and severe infections [4]. The most common causes of death in childhood from SCD are infection, acute chest syndrome, and stroke [5].

SCD children have a chronic inflammatory condition that often results in low local oxygen tension leading to sickling of erythrocytes, increased blood viscosity, and thrombosis with subsequent ischemic tissue break down [6]. Furthermore, $30 \%$ of all gallstones in children have been reported to be due to hemolytic diseases such as sickle cell disease, hereditary spherocytosis, and thalassemia [7]. Vaso-occlusive events are the most common complication experienced by both children and adults with SCD, and there are few treatment options to prevent the development of these events [6]. The care of patients with SCD is largely supportive of hydroxyurea representing the only widely used drug, which modifies disease pathogenesis [2].

Immunoglobulins (Ig) are a family of structurally related proteins which mediate circulating antibody responses. There are five major classes of Ig, namely IgG, IgA, IgM, IgD, and IgE, respectively. Each class includes a light (L) chain and a distinct heavy $(\mathrm{H})$ chain. IgM is the first class of antibody to appear in the serum after exposure to an antigen. IgG is the antibody present in the highest concentration in the serum, and it is called gamma globulin because of its electrophoretic and solubility characteristics. IgA is the major class of antibody in external secretions such as saliva, tears, and bronchial mucus. Thus, IgA serves as the first line of defense against bacterial and viral antigens. The role of IgD is not yet known. IgE is important in conferring protection against parasites, and it also causes allergic reactions [8]

Lipids are molecular organic compounds composed largely of carbon and hydrogen that are essential for cell growth. Lipids are nonsoluble in water and combine with carbohydrates and proteins to form the majority of all plants and animal cells. The three major purposes of lipids are energy storage, cell membrane development, components 
of hormones, and vitamins in the body. In healthcare, physicians order lipid tests or lipid profile to measure cholesterol and triglyceride levels in patient's blood. People with high triglycerides levels often have high total cholesterol (TC), a high cholesterol LDL, and low cholesterol HDL levels. Studies have shown that high levels of TC, triglycerides (TG) (greater than or equal to $200 \mathrm{mg} / \mathrm{dL}$ ) [9], low-density lipoproteincholesterol (LDL-C) and apolipoproteins A-I, and low levels of high-density lipoprotein cholesterol (HDL-C) are the risk factors of cardiovascular disease [10].

\section{METHOD}

\section{Subject selection}

Children diagnosed with sickle cell anemia at Ekiti State University Teaching, Ado Ekiti State and Federal Medical Centre, Ido Ekiti, were used as the subject for this study. A total of 120 sickle-celled children were used between the ages 1-8 years old. The participants used for the control were 80 healthy children between the ages 1-8 years old. They were tested and confirmed nonsickle cell patients. The participants' age and weight were also measured and recorded. A total of 200 participants were used for this research work. Informed written consent was provided by all participants. Ethical approval was obtained from Ekiti State University Ethics Committee.

\section{Sample collection}

The blood samples used for the test were collected from sickle-celled patients, and nonsickle celled patients at Ekiti State University Teaching Hospital, Ado-Ekiti, and Federal Medical center, Ido-Ekiti, Ekiti State, Nigeria. Intravenous blood $(5 \mathrm{~mL})$ was collected from the patients using a sterile syringe. It was carefully dispensed into a fluoride oxalate bottle to avoid blood clotting. The blood plasma of the children was used as samples.

\section{Determination of plasma Ig}

The plasma Ig was determined using the ELISA method as described by Malvano et al. [11].

\section{Determination of plasma lipid profile}

\section{Estimation of TC}

Plasma TC in all the samples collected from the participants was analyzed by the cholesterol CHOD-PAP method (an enzymatic endpoint method) as described by Trinder [12].

\section{Estimation of HDL-C}

HDL in the sample was separated by precipitation through the procedure adopted by Lopes- Virella [13].

\section{Estimation of $L D L-C$}

LDL-C concentration in the sample was determined using the relationship as described by Fredrickson-Friedewald [14].

\section{Estimation of VLDL-C}

The concentration of VLDL-C in the sample was analyzed by a simple relationship described by Fredrickson-Friedewald [14].

\section{Estimation of TG}

TG was determined using GPO-PAP method of Randox diagnostic kit as described by Trinder [12].

\section{Data analysis}

The results obtained were grouped and expressed as a mean \pm standard error of the mean. The data collected was analyzed using one-way analysis of variance and Duncan multiple range tests to compare the data obtained from the experiment to those of the control [15].

\section{RESULT}

Table 1 shows the concentration of Ig (IgM, IgG) and lipid profile (TC, HDL-C, LDL-C, VLDL-C, and TG) of nonsickle cell and sickle-celled
Table 1: Parameters showing Ig and lipid profile of nonsickle cell children and sickle-cell children

\begin{tabular}{llll}
\hline Parameters & AA & AS & SS \\
\hline IgM (g/L) & $2.52 \pm 0.32^{\mathrm{a}}$ & $2.30 \pm 0.29^{\mathrm{a}}$ & $1.47 \pm 0.31^{\mathrm{b}}$ \\
IgG (g/L) & $4.18 \pm 0.45^{\mathrm{a}}$ & $3.89 \pm 0.41^{\mathrm{a}}$ & $2.97 \pm 0.47^{\mathrm{b}}$ \\
TC (mmol/L) & $2.17 \pm 0.62^{\mathrm{a}}$ & $2.31 \pm 0.59^{\mathrm{a}}$ & $3.41 \pm 0.61^{\mathrm{b}}$ \\
HDL-C (mmol/L) & $1.95 \pm 0.42^{\mathrm{a}}$ & $1.87 \pm 0.40^{\mathrm{a}}$ & $1.10 \pm 0.39^{\mathrm{b}}$ \\
LDL-C (mmol/L) & $0.63 \pm 0.50^{\mathrm{a}}$ & $0.70 \pm 0.55^{\mathrm{a}}$ & $1.27 \pm 0.6^{\mathrm{b}}$ \\
VLDL-C (mmol/L) & $0.19 \pm 0.18^{\mathrm{a}}$ & $0.27 \pm 0.2^{\mathrm{a}}$ & $0.71 \pm 0.22^{\mathrm{b}}$ \\
TG (mmol/L) & $0.42 \pm 0.30^{\mathrm{a}}$ & $0.54 \pm 0.28^{\mathrm{a}}$ & $0.92 \pm 0.32^{\mathrm{b}}$ \\
Age (years) & $3.70 \pm 2.0^{\mathrm{a}}$ & $3.85 \pm 2.1^{\mathrm{a}}$ & $3.84 \pm 2.1^{\mathrm{a}}$ \\
Weight (kg) & $18.10 \pm 1.6^{\mathrm{a}}$ & $16.01 \pm 2.0^{\mathrm{a}}$ & $12.91 \pm 2.0^{\mathrm{b}}$ \\
pH & $8.81 \pm 0.15^{\mathrm{a}}$ & $7.71 \pm 0.6^{\mathrm{a}}$ & $7.59 \pm 0.5^{\mathrm{a}}$ \\
\hline
\end{tabular}

Results are expressed as a mean and standard deviation. $\mathrm{P}<0.05$,

superscript $\mathrm{t}^{\mathrm{a}}$ and ${ }^{\mathrm{b}}$ indicates significant differences. AA: Homozygous normal red blood cell, AS: Heterozygous normal red blood cell, SS: Sickle cell disease, HDL-C: High-density lipoprotein cholesterol, LDL-C: Low-density lipoprotein cholesterol, VLDL-C: Very low-density lipoprotein cholesterol, Ig: Immunoglobulin

children. There was a significant decrease in the concentration of IgM and IgG in abnormal hemoglobin carriers compared to the normal hemoglobin carriers $(\mathrm{P}<0.05)$. Furthermore, the concentration of $\mathrm{TC}$, LDL-C, VLDL-C, and TG significantly increased in abnormal hemoglobin carriers compared to the normal hemoglobin carriers $(\mathrm{P}<0.05)$ whereas HDL-C concentration showed a significant decrease in abnormal hemoglobin carriers compared to the normal hemoglobin carriers $(\mathrm{P}<0.05)$.

The weight of abnormal hemoglobin carriers compared to the normal hemoglobin carriers $(\mathrm{P}<0.05)$ decreased significantly whereas the plasma $\mathrm{pH}$ and age of abnormal hemoglobin carriers showed no significant difference $(\mathrm{P}<0.05)$ compared to the normal hemoglobin carriers.

\section{Findings}

This study investigated the level of Ig (IgG and IgM) and lipid profile (TC, LDL-C, VLDL-C, and TG) of sickle cell anemia patients (SS) compared to homozygous normal hemoglobin (AA) and heterozygous normal hemoglobin (AS) participants.

Ig is proteins, which mediate circulating antibody responses. There was significantly decrease in the levels of Ig (IgM and IgG) in sickle-celled children. According to Ballas et al. [16], the reduced level of IgM in sickle cell anemia could be due to functional asplenia whereas the reduced level of IgG could be due to the susceptibility of the patients to infections [17].

Furthermore, the concentration of TC, LDL-C, VLDL-C, and TG significantly increased in sickle-celled children whereas HDL-C concentration showed a significant decrease. This is in agreement with the works of Alassane et al. [18], who observed a negative association between HDL-C and triglyceride and VLDL. These show that HDL-C as measured by its concentration may function as a prognostic marker of intravascular hemolysis and endothelial dysfunction given its antiinflammatory, antioxidative, antiaggregation, anticoagulant, and profibrinolytic activities [19].

Magda et al. [19] also stated that patients with lower HDL-C levels were likely to have had more blood transfusions; this can be linked with a more severe clinical course of the disease, once that it is a therapeutic strategy used to prevent several clinical symptoms such as stroke. The combined effects of decrease in HDL-C, increased oxidized LDL status, raised triglyceridemia, and TG/HDL-C ratio in SCA patients [18]. The raise in this index and in the triglycerides, strongly implicated in the atherogenic process suggests an increased risk of atherosclerosis during SCA [20]. These lipid abnormalities could represent a cardiovascular risk for SCD patients. 
The mean age and pH value for both normal hemoglobin carrier (AA) and sickle cell patient were insignificantly difference, which means age and $\mathrm{pH}$ might be not determining factor in sickle cell anemia in children. Whereas the weight of sickle children reduced significantly, this indicates that this hemoglobin type affects their weights. This is in agreement with the findings of Mukherjee and Gangakhedkar [21], who stated that children with SCD weigh less, are shorter and undernourished as compared to normal children.

\section{CONCLUSION}

IgG and IgM and lipid profile were implicated in sickle-celled anemia in Ekiti State. It could, therefore, be concluded from this study that immune dysfunction and lipid abnormalities are evident in SCD children in Ekiti state, Nigeria. Therefore, the proper care for SCD children is required to prevent/limit cardiovascular risk and immune dysfunction, thereby increasing the chances of survival.

\section{ACKNOWLEDGMENT}

All the Professors in the Department of Biochemistry, Ekiti state university, Nigeria, and the chief technologists of the university are highly appreciated for their contributions that made this research work a success. Furthermore, all the subjects that participated in this research study are appreciated for their consent.

\section{AUTHOR'S CONTRIBUTION}

O.A.O. and O.O.G. conceived and designed the research study. O.A.O. and O.O.G. performed the experiment and data collection. O.A.O. carried out data analysis and interpretation with support from 0.O.G. O.O.G. wrote the manuscript with support from O.A.O . O.A.O. and O.O.G. revised the manuscript critically. O.A.O. and O.O.G. made the final approval of the manuscript to be published.

\section{CONFLICT OF INTEREST}

The authors declare that there are no conflicts of interests regarding the publication of this paper.

\section{REFERENCES}

1. Oyeyemi AO, Sonuga AA, Oyebanji OG. Comparism of antioxidants status among children, teenagers and adults with sickle cell anaemia. Intern J Eng Sci Invent 2017;6 Suppl 7:18-21.

2. Kathleen AN, Julie AP. Pharmacotherapy of sickle cell disease. $18^{\text {th }}$ Expert Committee on the Selection and Use of Essential Medicines; 2011. p. 1-16.

3. American Academy of Pediatrics. Policy statement. Health supervision for children with sickle cell disease. Pediatrics 2002;109:526-35.
4. Nagababu E, Fabry ME, Nagel RL, Rifkind JM. Heme degradation and oxidative stress in murine models for hemoglobinopathies: Thalassemia, sickle cell disease and hemoglobin C disease. Blood Cells Mol Dis 2008;41 Suppl 1:6066.

5. Quinm CT, Rogers ZR, Mccavit TL, Buchanan, GR. Improved survival of children and adolescent with sickle cell disease. Blood 2004; $115: 3447-52$

6. Oyeyemi AO, Oyebanji OG, Akinlua I. Evaluation of antioxidant enzymes in children with sickle cell anaemia in Ekiti state, Nigeria. J Med Dent Sci Res 2016;3 Suppl 7:1-4.

7. Abdullah UY, Jassim HM, Baig AA, Khorsheed RM, Al-Khayat AM, Sulong AF, et al. Gallstones in patients with inherited hemolytic diseases. Int J Pharm Pharm Sci 2015;7:9-15.

8. Goldsby RA, Kindt TJ, Osborne BA, Kuby J. Immunology. New York: W.H Freeman and Company; 2003. p. 5.

9. Gotto AM. Triglyceride: The forgotten risk factor. Circulation 1998;97:1027-8

10. Abdel-Reheim ES. Cardioprotective efficacy of taurine on lipidmetabolism of isoproterenol-induced myocardial infarction. Int $\mathrm{J}$ Pharm Pharm Sci 2016;8:135-40.

11. Malvano R, Rook GA, Jannuzzi C, Voller A. Enzyme-linked immunosorbent assay for quantitation of toxoplasma antibodies in human sera. J Clin Pathol 1981;53:635-7.

12. Trinder P. Report of the national cholesterol educational program. Expert panel on detection, evaluation and treatment of high blood cholesterol in adults. Arch Intern Med 1988;148:36-9.

13. Lopes-Virella MF. HDL - Cholesterol precipitant. Chemestry 1977;23:882-5.

14. Fredrerickson-Friedewald WT. Method for the determination of LDLcholesterol. Clin Chem 1972;18:499-502.

15. Zar JH. Biostatistical Analysis. $2^{\text {nd }}$ ed. Upper Saddle River, NJ: Prentice Hall Inc.; 1984. p. 106

16. Ballas SK, Burka ER, Lewis CN, Krasnow SH. Serum immunoglobulin levels in patients having sickle cell syndromes. Am J Clin Pathol 1980;73 Suppl 3:394-6.

17. Dieye TN, Ndiaye O, Ndiaye AB, Thiam D, Fall-Seck K, Diop S, et al. Complement and serum immunoglobulins in homozygous and heterozygous sickle cell anemia in Senegal. Dakar Med 1999;44 Suppl 2:175-9.

18. Alassane D, Fatou C, Fatou GT, Fatou D, Oumar TF, Ndéné SG, et al. Serum lipids and oxidized low density lipoprotein levels in sickle cell disease: Assessment and patho biological significance. Afr J Biochem Res 2014;8 Suppl 2:39-42.

19. Magda OS, Larissa CR, Mauricio BC, Joelma FM, Isa ML, Valma ML, et al. Levels of high-density lipoprotein cholesterol (HDL-C) among children with steady-state sickle cell disease. Lipids Health Dis 2010;9:91.

20. da Luz PL, Favarato D, Faria-Neto JR, Lemos P, Chagas AC. High ratio of triglycerides to HDL-cholesterol predicts extensive coronary disease. Clinics 2008:64:427-32.

21. Mukherjee MB, Gangakhedkar RR. Physical growth of children with sickle cell disease. Indian J Hum Genet 2004;10 Suppl 2:70-2. 